\section{Nutritional diagnosis in children}

Dear Editor

This comment refers to the article ${ }^{1}$ recently published in Jornal de Pediatria. The aim of the study was to assess the nutritional status of children and adolescents with post-infectious bronchiolitis obliterans. The authors, however, seem to have misinterpreted the results concerning the diagnosis of "malnutrition." An accurate assessment would demonstrate that the weight-for-age (W/A) parameter should overestimate the prevalence of "malnutrition" as opposed to the results presented which underestimated the diagnosis of "malnutrition" when the weight-for-height (W/H) anthropometric relation was compared to the W/A parameter, since this index tends to consider all children to be the same height at a certain age. Thus, a child shorter than the average with adequate weight-for-height status would be misclassified as "malnourished" by the W/A index. This situation could be clearly observed in this study, which showed high prevalence of stunted children. The World Health Organization $(\mathrm{WHO})^{2}$ has recommended in a recent document that the W/A index should be used only in countries in which minimum stature, and therefore $\mathrm{W} / \mathrm{H}$, is a condition impossible to be achieved. The authors' technical position diverged when reporting that "the use of weight/age is very appropriate for tracking weight gain in children...," when compared to the article on the new reference curves by the $\mathrm{WHO}^{2}$ which states the following: "Weight-for-age is inadequate for monitoring growth beyond childhood due to its inability to distinguish between relative height and body mass..." Thus, the authors' statement that W/A is better than W/H came as a surprise to us, since it is based on a concept not validated by the WHO (pp. 162 and 163), ${ }^{3}$ which - in the origin of the term to diagnose nutritional deficit - uses "wasting" for W/H and "underweight" for W/A, calling attention to a possible occurrence of stunting in the latter. The WHO also recommends not using the term malnutrition for deficits obtained exclusively by anthropometric parameters. The deficit in body nutritional reserve should be measured by $\mathrm{W} / \mathrm{H}$ and, when detected, nutritional intervention would play a central role in reestablishing this deficit. The presence of short stature $(\mathrm{H} / \mathrm{A})$ may result from sequelae from previous impairments, such as birth length, in which a nutritional approach may result in little or no effect over this reestablishment. Therefore, $\mathrm{W} / \mathrm{H}$ and $\mathrm{H} / \mathrm{A}$ should be analyzed separately concerning the presence of nutritional deviations, differently from the analysis published by Waterlow, ${ }^{4}$ whose classification is no longer used in current investigations. The finding concerning high prevalence of low weight assessed by body mass index-for-age in adolescents shown in Table $1^{1}$ may be associated with puberal stage, since adolescents who show delay in this process are often misdiagnosed as having low weight and height because they present weight and height values lower than those of the reference population at percentile 50. For these reasons, we disagree with the conclusions addressed by the authors regarding the application of anthropometric parameters and we recommend closer attention concerning the classification parameters to be adopted in the assessment of nutritional status in children and adolescents, regardless of the associated pathologies.

\section{References}

1. Bosa VL, de Mello ED, Mocelin HT, Benedetti FJ, Fischer GB. Assessment of nutritional status in children and adolescents with post-infectious bronchiolitis obliterans. J Pediatr (Rio J). 2008; $84: 323-30$

2. de Onis M, Onyango AW, Borghi E, Siyam A, Nishida C, Siekmann J. Development of a WHO growth reference for school-aged children and adolescents. Bull World Health Organ. 2007;85:660-7.

3. World Health Organization (WHO). Physical status: the use and interpretation oh anthropometry, Geneva: WHO; 1995.

4. Waterlow JC. Note on the assessment and classification of protein-energy malnutrition in children. Lancet. 1973;2:87-9.

doi: 10.2223/JPED. 1841

No conflicts of interest declared concerning the publication of this letter.

\section{Márcia Regina Vitolo}

Doutora, Universidade Federal de Ciências da Saúde de Porto Alegre (UFCSPA), Porto Alegre, RS, Brazil.

\section{Paula Dal Bó Campagnolo}

Mestre, UFCSPA, Porto Alegre, RS, Brazil.

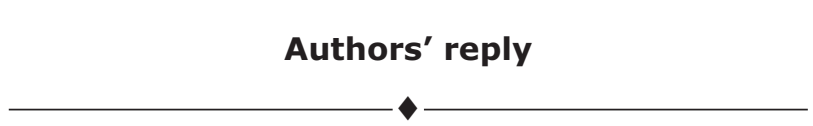

Dear Editor,

We thank the authors for their critical comments on our article $^{1}$ and we are glad that considerable interest has arisen from both the text and the theme. Assessment of nutritional status is a complex matter, since there are several methods for nutritional assessment as well as several classifications available in the literature, ${ }^{2,3}$ which resulted in this letter to the editor.

For this reason, in our study ${ }^{1}$ we used for the nutritional classification of our population the anthropometric indices commonly used for nutritional assessment and validated by the World Health Organization (WHO) and the Brazilian Ministry of Health, i.e., weight-for-age (WA), weight-for-height 
$(\mathrm{WH})$, height-for-age $(\mathrm{HA})$, and body mass index (BMI). ${ }^{3,4}$ For children (under 10 years of age), we used WH and HA for classification as malnutrition and/or short stature and WA for risk for malnutrition, according to the model proposed by Dornelles et al. ${ }^{5}$ With respect to nutritional status, Table $1^{1}$ clearly demonstrates that the $\mathrm{HA}$ and WA variables showed a greater alteration than the WH variable. These data should not lead to a misinterpretation that, in our study, one index is better than the other, since we aimed to value the guidelines from the WHO and the Brazilian Ministry of Health which recommend the use of three indices. We may consider that, in the present study, concerned with obtaining a more detailed nutritional assessment, the other parameters used (e.g., body composition) reinforce the conclusions concerning the high incidence of malnutrition and/or low muscle reserve (muscular circumference of the arm, MCA $=50.9 \%$ of patients with low muscle reserves). Regarding short stature, it is known that it may reflect constitutional short stature, as well as chronic malnutrition. Chronic disorders usually interfere with growth, compromising stature or causing bone age delay. ${ }^{6}$ If we had focused solely on $\mathrm{WH}$, we would not have identified these cases and, therefore, not acted towards their improvement.

The possible association with puberal stage in the adolescents was considered in the study; however, the small number of patients in the categories analyzed prevented us from carrying out deeper analyses. Additionally, the statistical analyses performed in these groups did not interfere in the final results and were not presented in this study due to publishing limitations. Since this group of patients is being currently followed up, we believe that, in a near future, we can present such results with more consistent figures.

Nevertheless, this letter highlights the importance of not generalizing criteria in the assessment of nutritional status. The criteria concerning malnutrition, low weight and risk for malnutrition should be determined for each population to be studied, especially when associated comorbidities are present.

\section{References}

1. Bosa VL, de Mello ED, Mocelin HT, Benedetti FJ, Fischer GB. Assessment of nutritional status in children and adolescents with post-infectious bronchiolitis obliterans. J Pediatr (Rio J). 2008; $84: 323-30$

2. de Mello ED. O que significa a avaliação do estado nutricional. J Pediatr (Rio J). 2002;78:357-8.

3. World Health Organization. WHO Child Growth Standards: length/height-for-age, weight-forage, weight-for-length, weight-for-height and body mass index-for-age. Methods and development. WHO (nonserial publication). Geneva: WHO; 2006.

4. Brasil. Ministério da Saúde. Vigilância alimentar e nutricional SISVAN: Orientações para a coleta e análise de dados antropométricos em serviços de saúde. Material preliminar. Brasília: Ministério da Saúde; 2008.

5. Dornelles CT, Piva JP, Marostica PJ. Nutritional status, breastfeeding and evolution of infants with acute viral bronchiolitis. J Health Popul Nutr. 2007;25:336-43.

6. Zeferino AM, Barros Filho AA, Bettiol $H$, Barbieri A. Acompanhamento do crescimento. J Pediatr (Rio J) 2003;79 Supl 1:S23-32.

doi: $10.2223 /$ JPED. 1842

No conflicts of interest declared concerning the publication of this letter.

\section{Vera Lúcia Bosa}

Nutricionista. Mestre, Universidade Federal do Rio Grande do Sul (UFRGS), Porto Alegre, RS, Brazil.

\section{Elza Daniel de Mello}

Doutora. Médica e nutricionista, Serviço de Nutrologia, Hospital de Clínicas de Porto Alegre (HCPA), Porto Alegre, RS, Brazil.

\section{Helena Teresinha Mocelin}

Doutora. Médica, Serviço de Pneumologia Pediátrica, Hospital da Criança Santo Antônio (HCSA), Irmandade Santa Casa de Misericórdia de Porto Alegre (HCSA-ISCMPA), Porto Alegre, RS, Brazil.

\section{Franceliane Jobim Benedetti}

Nutricionista. Mestre, UFRGS, Porto Alegre, RS, Brazil.

\section{Gilberto Bueno Fischer}

Doutor. Professor titular, Pediatria, Universidade Federal de Ciências da Saúde de Porto Alegre (UFCSPA), Porto Alegre, RS, Brazil. Professor, Programa de Pós-Graduação em Ciências Médicas: Pediatria, UFRGS, Porto Alegre, RS, Brazil. Médico, Serviço de Pneumologia Pediátrica, HCSA-ISCMPA, Porto Alegre, RS, Brazil. 